\title{
To What Extent does CEO Behavior Enhance Risk-Taking? A Banking Sector Related Evidence
}

\author{
Wafa Jilani*, Jamel Chouaibi**
}

\begin{abstract}
The present paper is designed to examine the extent of the Chief Executive Officer's (CEO) behavioral impact on the bank risk-taking venture. The sample involves a set of 540 banks, observed over a longitudinal panel data set (2007-2019). A multiple linear-regression technique has been applied. The attained results prove to highlight that when CEOs seem to enjoy a great deal of overconfidence, they are more likely to influence the board's decision-making to their proper risk-reducing advantage. The greater the CEO dominance is, the more decreased the bank specific risk turns out to be, given the significantly positive association of CEO dominance with the risk-taking procedure. This paper's results have implication for banks and policymakers looking to promote risk-taking. This paper could be useful to shareholders as they aim to recruit the most gifted CEOs with the relevant set of competences in order to meet shareholders' goals and enhance bank competitiveness.
\end{abstract}

Keywords: bank risk-taking; corporate governance; CEO behavior; CEO dominance.

JEL classification: G23, G32, G41.

\section{INTRODUCTION}

The role banks play in maintaining economic growth constitutes an essential motivation lying behind the investors' as well as the supervisory authorities' permanent control of the institutions. Indeed, while investors are interested in satisfying, safeguarding and preserving their proper capital revenues' interest expectations, control authorities take interest in maintaining the banking system's overall financial stability. Following the subprime crisis of 2007, concerns about bank corporate governance grew, with the goal of reshaping Models of banking business and regulating them. This is due to the thought that the causes of the financial crisis are linked to corporate governance in the banking industry. The collapse of multiple governance systems has frequently been cited as one of the crises' key causes (De

\footnotetext{
* Faculty of Economics and Management of Sfax, University of Sfax, Tunisia; e-mail: wafajilani94@gmail.com (corresponding author)

*** Faculty of Economics and Management of Sfax, University of Sfax, Tunisia; e-mail: chouaibi_jamel@yahoo.fr.
} 
Haan and Vlahu, 2016; Handriani et al., 2021). Beltratti and Stulz (2012) indicated that Banks with careful corporate governance structures are thought to be more effective in allocating their investment, while banks with weak governance and excessive risk taking suffer greater losses since they are riskier during the crisis.

In this respect, risk taking stands as a major indicator justifying the evaluative processes associated with banking profitability and economic financial stability. As a matter of fact, banks are highly vulnerable to risk taking for several reasons, mainly, the high leverage levels, limited market discipline from the part of creditors, along with their potential disposition to unexpectedly sharp asset-risk increases. Additionally, bank failures might well turn out to be exorbitant for the taxpayer, and bring about detrimental impacts on the real economy. Hence, a substantial academic and regulatory debate is persistent as to the extent to which governance related weaknesses could lead to bank risk exposure. It is commonly maintained that the banking sector associated vulnerability has its origins in excessive risk accumulation perceived throughout the crisis initially triggered in 2008 (DeYoung and Torna, 2013; Abdul Hamid et al., 2020).

Actually, a survey of relevant governance and risk literature reveals well that shareholder-orientated governance helps in further exacerbating bank risk-taking and entails the availability of efficient mechanisms whereby the other stakeholders' interests could be effectively protected (Srivastav and Hagendorff, 2016). Indeed, bank risk-taking has for long made subject of intense research from the part of specialists, policy makers, and professionals. In this regard, several legislations and regulatory reforms have been enacted recommending banks to conduct and track various bank related practices, including risk-taking, in a bid to restore a rather sound and competitive banking system. Yet, such monetary policies may well result in altering the banks' perceptions of risk, which might in turn affect the banks' risk aversion statuses (Borio and Zhu, 2012; Boungou, 2020). Also, the bank debt holders do not often have strong incentives, and are not usually motivated enough, to track bank activities, owing mainly to the scattered nature of depositors, along with the requisition of involving deposit insurance schemes. Consequently, risk aversion has turned out to fade away with limited liability (Broll et al., 2018). There is, however, an incentive for banks to take undue risks, as they do not bear the full impact of keeping risky portfolios (Behr and Wang, 2020). Accordingly, banking systems pursuing risky strategies and policies as effective monetary transmission mechanisms are certainly more disposed to achieve remarkable yields as to the stability of the banking system as well as the economy as a whole in the light of the recent financial crises (Altunbas et al., 2020).

Moreover, based on the upper echelons theory, one may well argue that, in respect of other decision makers, CEOs are often distinguishable for minimal rationality. This denotes well that CEOs are often apt to make decisions relying on their particular social, behavioral, and psychological traits or characteristics (Orens and Reheul, 2013). In this respect, the topechelon theory generally maintains that CEO discretion is primarily affected with prevalent cognitive, psychological, and social factors. Still, despite the predominance of this great deal of relevant literature, most researchers do not often tend to accord the top bank executives' marking features enough importance. In this regard, Bandiera et al. (2020) consider that behavioral characteristics, such as optimism and aversion to managerial risk, turn out to be noticeably correlated with corporate risks. As for Aabo et al. (2020), they have discovered that overconfident CEOs turn out to be increasingly orienting their investments towards risky ventures. Accordingly, such studies tend to deem the managerial specific characteristics as significant risky corporate decision-taking factors. Nevertheless, if bank performance is under 
optimum and bank risk is weak, CEOs who face a risk of turnover can earnestly pursue risk in order to take advantage of the safety net and improve bank performance in order to keep their job. If a bank's performance has been low and its risk level is elevated, the CEOs of banks may be more interested about their professional image and potential job prospects, as well as unexpected bank audits. As a result, they may be less willing to take chances in order to minimize the possibility of losses (Chen and Ebrahim, 2018).

It is also important to note that further extending the bank related risk-motivation explanation by incorporating a behavioral-finance approach would also be effectively beneficial, as most of the corporate decision-making involved individuals are inevitably subject to cognitive biases. As a matter of fact, certain CEO specific psychological attributes are particularly associated with overestimating expected future investment and venture related cash flows and their potential risks, which might eventually bring about unnecessary risk-taking.

On accounting for these considerations, the present work is designed to provide plausible answers to the following questions: Are the dominant CEO managed banks more avert to risk? To what extent does CEO duality restrict the relationship between CEO dominance and risktaking? In what ways does CEO overconfidence influence Bank risk-taking venture?

Accordingly, the study's major purpose lies in investigating the CEO's behavioral impact on the bank's risk-taking decisions.

The empirical analysis appears to reveal well that the impact of CEO dominance on risktaking turns out to be noticeably influential. More particularly, in the cases where the CEO is perceived to be relatively more dominant, increased CEO dominance appears to be rather associated with greater risk-taking. Indeed, CEOs seem to get involved and indulge in risky strategies to the extent that they are confident that their power is well established. At this level, they turn out to be rather unwilling to engage with other top executives, culminating in the predominance of less balanced and riskier strategies. More importantly, however, is that a stronger CEO behavior may well help in effectively monitoring and disciplining a CEO in a bid to achieve a rather efficient performance. In effect, a stiff and rigid CEO behavior could well entice and induce the CEO's decision making policies to inhibit greater deals of risktaking. Additionally, a stronger CEO behavior may well yield lower communication and coordination costs to be incurred, thereby, maintaining a positive effect the CEO power could have on the bank's risk-taking strategy. In this context, we hypothesize that the stronger the CEO's behavior is, the greater the impact of the CEO's dominance on the bank would be. Accordingly, the study undertakes to measure the banks' risk-taking decisions based on multidimensional risk features. To this end, we consider applying the Principal Component Analysis (PCA) approach to narrowly examine the underlying structure of bank risk-taking proxies, and retrieve the most appropriately relevant variable fit for effectively embodying the risk-taking process.

In this way, the present study is modestly conceived to contribute in enriching the relevant literature in several folds. In a first place, the data set applied has the advantage of providing general conclusions as to the above cited theoretical considerations. To our knowledge, only very few studies have undertaken to address the complex relationship binding risk taking and CEO behavior within the banking sector's context at a worldwide level. As to the second major contribution, it lies in our consideration to opt for a novel testing route assessment procedure whereby corporate governance way well indirectly impact the banks' risk taking policies. More specifically, we reckon to investigate how the CEO's predominance effect on the bank's risk-taking policy can change in presence of CEO duality. 
In a final stage, we undertake to analyze in what ways an over-dominant CEO contributes in further increasing the bank's risk-taking strategy, and is too reluctant to opt for new business models exclusively oriented to improve bank profitability in the short term.

The paper is planned as follows. Section 2 is devoted to constructing the relevant hypotheses. As to Section 3, it deals with outlining the research methodology, including the sample data, variable measures as well as the empirical model implementation. Concerning Section 4, it serves to highlight the descriptive statistics along with the reached empirical results. As regards the robustness test achieved results, they make subject of Section 5 . Finally, Section 6 bears a summary of the major attained findings, along with the main concluding remarks.

\section{LITERATURE REVIEW AND HYPOTHESES DEVELOPMENT}

Currently, the bank CEO appears to stand as a central axe mechanism, whereby, the managerial risk-taking behavior can be effectively monitored. In fact, having a strong CEO as a head of a banking institution is crucial for ensuring that the board's governance structure is predominantly focused on treating the appropriately critical issues. Diallo (2017) affirmed that the government's safety net decreases stakeholders' motivations to control banks, allowing bank CEOs to "gamble for resurrection. Calomiris and Ramirez (2018) maintained that the may be because bank boards actively allow CEOs to take more chances in order to profit from the safety net. According to Chen and Ebrahim (2018), the Bank CEO may not decrease risk-taking, even though banking performance is pauperized and the level of sales threat is rising as a result. However, regulations for bank reviews could make it harsh, for CEOs to substantially set risk-taking in the event of bank performances.

Using a study of Chinese banks from 1999 to 2011, Ting et al. (2017) showed that the effects of various powerful features on bank output and board composition vary in their own specific ways. They discover that CEOs with institutional influence have a negative impact on results but a positive impact on board diversity. CEOs with ownership, control improve results, but they have a negative impact on board competent and diversity. Banks with specialist managers not only do well, but also have gender-diverse boards of directors. Also, they proved that CEOs' prestige, influence has little effect on performance; those with power are more likely to nominate politically linked directors to the board of directors. This finding adds to the results of Fralich and Fan (2018), who found that politically connected CEOs are more likely to nominate bureaucrats to the board of directors. They say that CEOs with reputation control are more likely to have extensive social networks and to nominate bureaucrats to the board of directors. CEOs exercise their influence by influencing bank efficiency and governance. CEOs boost their banks by using their ownership and expertise. Alternatively, power enables CEOs to effectively enforce their plans, resulting in improved efficiency. Moreover, CEO compensation regulation can remove the overinvestment issue of risky policies in the form of a requirement of delayed compensation linear in overall payouts of the bank. Such a compensation agreement offers the CEO only incentives to put forward policies which increase the bank's overall value (Kolm et al., 2017).

CEOs are thought to be influenced by a various of behaviors, each of which is linked to a different degree of risk aversion. Due to these behaviors, CEOs can advance for a compensation policy that is not in the best interests of shareholders. The pay-for-performance combination has been demonstrated to encourage a manager to shift his or her risk appetite, 
and thus has an effect on banking strategies. Risk-taking managers will receive a greater proportion of compensation on performance and minus cash-based packages (Anilov and Ivashkovskaya, 2020). Furthermore, CEOs may wish to enhance the underlying share's volatility so that related options raise their value. In order to do this, the manager must make more investments in high-risk projects. The risk grows as the investment set of the manager (Caliskan and Doukas, 2015). The manager does not have any able risk burdens if his or her compensation is equity-based, particularly in the way of stock options. Such managers will commit more capital to high-return investment ventures and will prefer riskier investments. As a result, they'll have less cash on hand and will be able to pay out less dividends (Geiler and Renneboog, 2016).

In addition, Geiler and Renneboog (2016) proved that if the CEO's incentive package is risk-based, investors would receive a lower payout from the CEO. Minnick and Rosenthal (2014) pointed that if the payout is less risky, the manager will be paid more. Given the importance of risk tolerance and the appetite for risk of a specific CEO, the Board of Directors has established a frame to decide the risk level to be taken by the CEO. The incentive aspect of executive pay packages may play a significant role in such a system (Anilov and Ivashkovskaya, 2020). More particularly, we undertake to examine the CEO's specific behavior in as far as it represents a key corporate-governance factor whereby CEOs could pursue their decision-making policies.

\section{CEO dominance and risk-taking}

In a previously conducted work, it has demonstrated, through a number of settings, that individuals with dominant personalities usually have a remarkable tendency to monitor and manipulate their environment (Gomulya et al., 2019). Indeed, leaders with dominant power tend to have a hurting nature or character, significantly affecting their conceptions and ideas about the notion of power and politics. Hence, it follows that, relative to other executives, the dominant CEOs (identified as CEOs with very powerful TMTs (top management teams), tend to veer policies and restrict the information flow within the TMTs, thereby, negatively influencing strategic decision-making and, therefrom, the TMTs' firm running performance (Bauweraerts and Colot, 2018; Vandekerkhof et al., 2019). Indeed, dominant CEOs would most often be inclined to support the TMT decision-making process, requiring stuff to be promptly executed, and, as such, consider themselves as corporate heroes or saviors as (Kisfalvi et al., 2016).

Actually, the key CEO associated characteristics are often missing in the current relevant debates, which should normally be accounted for noticeably. For such a shortcoming issue to be effectively overcome, appeal to the upper echelons' theory seems imposed, for a rather concrete definition of the CEO corporate-risk related characteristics to be attained (Hambrick and Mason, 1984). It is worth noting that the upper echelon theory maintains that the top management teams' individual characteristics prove to affect the organization's strategic choices, which in turn affect its performance. By applying this theory, Abatecola and Cristofaro (2018) attempted to reformulate the notion of firm success by incorporating a set of TMT associated psychological, sociological and economic factors, thereby, providing a clearer understanding of organizational behavior.

In academic research, however, the way CEO dominance impacts organizational risktaking strategy seems to be noticeably overlooked. Very few are those studies conducted to demonstrate that a firm's output volatility is actually correlated with the CEO's dominant 
character. In turn, Cheng et al. (2013) documented that a firm's output variability is generally enhanced by CEO dominance. With respect to Tang and Crossan (2017), they collected a set of 147 firms related data observations, relevant to the period 1999-2011. They ended up by affirming that investors could well pay a noticeable attention to banks with more dominant CEOs because they would be rather apt to offer greater advantages. Hence, should the bonus be set ahead, the compensation might well be greater for the management, while losses could be restricted to job security and prestige, and the owner is liable to incur total profit loss.

For the purpose of evaluating the extent of the CEO characteristics' effects on risktaking., Adams and Jiang (2017) applied a longitudinal panel data collection (1999-2012), gathered from the UK property-casualty insurance industry. They concluded that stock returns are discovered to be rather volatile with respect to the businesses in which the CEO proved to enjoy a considerable decision-making control. In effect, dominant CEOs would provide power and guidance to strategic resource-allocation decisions, while inspiring risk-taking policies to help the company maintain economic advantages over its competitors and gain above-average returns from shareholders (Elamer et al., 2018). Hence, the first hypothesis may be formulated as follows:

H1: CEO dominance is positively associated with bank risk-taking.

\section{CEO Overconfidence and Risk-taking}

The CEO's overconfidence is described as the propensity to overestimate his/her capacity to various activities, decision-making procedures and 'optimism' prospects. Indeed, overconfident bank executives are more prone to believe that potential expectations for loan recovery and profitability would be strong than unconfident executives. Thus, they would tend to overestimate efficiency, underestimate loan loss, and consider provisions lower than other managers would do. In this regard, Doukas and Petmezas (2007) suggest that managerial overconfidence is the by-product of self-attribution bias. Similarly, Hambrick and Crossland (2018) consider that excessive trust in CEOs might well culminate in quicker, less detailed, and more centralized decisions.

In this respect, the agency theory stipulates that shareholders are often exposed to the separation of shareholders and management, divergent goals and risk preferences between managers and shareholders, and encounter difficulties in monitoring managerial behavior. As to the monitoring expense, it is the expense charged by the director to assess, track, and control an agent's behavior, including auditing, hiring, and firing executives (Brammertz, 2010). On the other hand, management has to construct mechanisms pinpointing the key obligations they have to represent, i.e., bail costs. Losses emanating from interest conflicts and benefit agreements are often suboptimal for the agency (Laeven and Levine, 2009).

Similarly, Gervais et al. (2011) expected an overinvesting state of overconfident CEOs to take place once they appear to have sufficient internal funds, while the capital markets or governance structures are discovered to be uncontrolled. Inversely, they should perceive to be lacking in adequate internal capital, they would tend to limit their investments due to perceived underestimation, as they would be reluctant to issue new equities. Richard Roll (1986) was one of the first to suggest that CEO risk-taking requires a high level of trust. The interviews with business CEOs conducted by Shapira (1995) shed light on the importance of trust in risk-taking. He discovered that CEOs hate comparing company risk-taking to gamble because of the pre-determined odds. Shapira's respondents expressed varying levels of trust in their capacity to monitor post decision incidents, as well as in their capacity to predict 
potential occurrences. On analyzing the different CEO risk avoidance and optimism characters, Graham et al. (2013) discovered that the United States pertaining CEOs appear to vary substantially in attitudes from the non-US CEOs. They also found that the greater the CEOs' risk-tolerance was, the more mergers and acquisitions their companies would undertake. Actually, the CEOs who grew up during the Great Depression were discovered to be rather too risk-averse, given their heavier reliance on internal finances. On using data relevant to the period ranging between 1996 and 2012, Malmendier and Tate (2015) provided a novel empirical evidence that overconfidence is important for corporate investment decisions within a framework that addresses the endogeneity of businesses financial constraints. In this respect, they suggested that risk averse CEOs should reduce their corporate risk exposure by taking action ahead of expiry.

In turn, Shrader et al. (2020) hired 246 subjects to take part in the risk-taking decisions investigation experiment. They discovered a strong association persisting between the directors' overconfident character and corporate risk-taking venture. Based on the rational assumption, O'Reilly and Hall (2021) affirmed attaining their assigned exercise optimum point and, therefrom, set a clear definition of a non-overconfident CEO. Indeed, to examine the relationship between CEO overconfidence and decision-making accuracy, 252 participants responded to this assignment. Accordingly, our second hypothesis turns out to be:

H2: CEO Overconfidence is negatively associated with bank risk-taking.

\section{CEO duality moderating effect}

Proponents of CEO duality argue that the CEO should balance or equate between the supervisory role and the administrative function, by acting as a reference between the executive and the board, thereby, guaranteeing the long-term well-being of the CEO and the council's board chair. In effect, the firm would rather align management interests with shareholder interests (Rezaee et al., 2020). Simultaneously, CEO duality would also tend to have a special effect on the overall risk taking policy. Indeed, it implies that power is exclusively concentrated in a single person. On the other hand, such a position may well limit the CEOs' major functions to considerable decisions, since they would exclusively stand as the only ones responsible for a loss. Some published investigations, dealing with the nature of CEO duality and the associated effects, appear to highlight the prevalence of a negative association between CEO duality and banks corporate risk, while recording a positive impact on the insurance companies' corporate risk (Benzing and Börner, 2015). In this regard, AzilaGbettor et al. (2018) state that CEO duality helps in strengthening and increasing the CEOs' likelihood to make uncontrolled decisions.

Similarly, the stewardship theory assumes that CEO is granted greater control by serving as board chair, he or she would be fully empowered and liable to lead in a rather stiff or rigid way (Desai et al., 2003). Thus, jointly integrating the CEO's position and the board's president title, the company would be run rather effectively, in compliance with the shareholders' interests. Accordingly, from a stewardship theory perspective, increased power would be reflected and manifested in improved efficiency and increased returns resultant from strong top management leadership, such as that of the CEO.

It is worth recalling that the agency theory accounts for several corporate governances related components and practices, including the directors' board, ownership structure and external control, which help in restricting the managers' opportunistic behavior, especially those seeking self-interest (Friedman Peahl et al., 2020). As managers and directors 
participate directly in company decision matters, corporate governance (CG) practices can be moderating in the relationship binding CEO dominance and corporate risk. The circumstances in which CEO dominance could help in reducing the risk-taking level need be rather clearly considered. Still, we have considered it useful to examine the CEO duality effect on the dominant CEO risk-taking character. In this context, Gyamerah et al. (2020) stressed that when the same individual holds both of the CEO and the Board Chairman positions, conflicts of interest are more imminently certain to take place, as she would dominate the board proceedings and monitor its meetings, thereby, overlooking the stakeholders' interests in riskdecision matters. In effect, one would expect that CEO duality would actually affect the CEO's dominance, therefore, affecting management risk. At this level, the following hypothesis can be advanced:

H3: CEO duality negatively moderates the CEO dominance and bank risk-taking relationship.

\section{Graphic model}

Figure no. 1, below, highlights the CEO duality's moderating role of the dominant CEO's risk-taking decisions, within a conceptual framework.

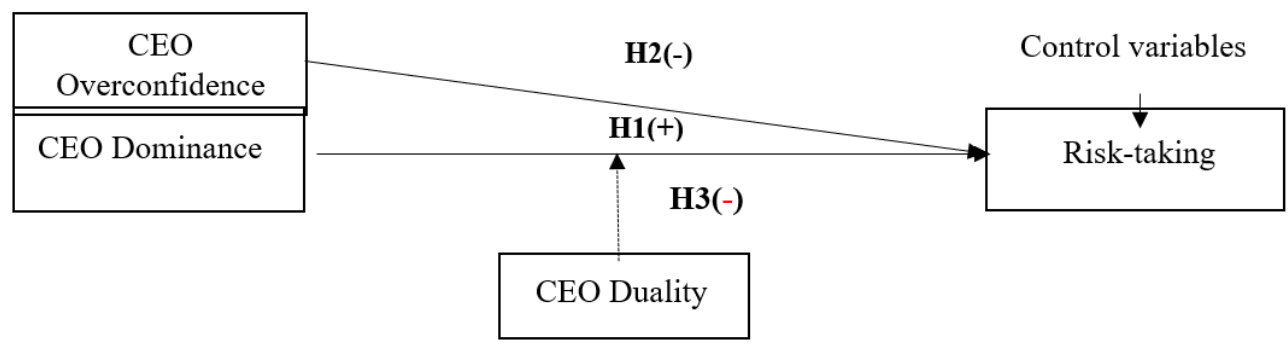

Figure no. 1 - Research Model

\section{RESEARCH METHODOLOGY}

\subsection{Sample and data collection}

For an effective empirical analysis of the CEO characteristics' impact on bank risktaking, we consider, in a first stage, examining an initial sample involving 800 commercial banks sited in 34 different countries, observed over the period ranging between 2007 and 2019. The banks' selection criterion rests on the most efficient results scored by these banks in their home countries. Banks regarding which data were unavailable or missing have been excluded. Hence, the final sample turns out to involve 540 banks and 7020 bank year observations. Panel A of Table no. 1 depicts the selection procedure undertaken. Panel B of the same table illustrates the sample description by region. Most of the sample banks appear to be installed in Europe (43.35\%), reflecting a remarkable capitalization of the banking market in the continent. A $20 \%$ proportion of the sample banks are sited in America. The remaining $6.65 \%$ of the sample banks are located in countries scattered in other regions. It is also worth citing that we decided to introduce a macroeconomic variable drawn from the world development indicators' database, while the bank financial data have been outsourced and collected from the Thomson Reuter (Datastream). As for the CEO related characteristics, 
they have been manually compiled from the relevant annual reports, Bloomberg and banks' websites. Table no. 1, below, sums up the sample selection procedures.

Table no. 1 - The sample selection procedure

\begin{tabular}{lll}
\hline Panel A : Selection procedure & & \\
\hline Initial population & Banks & Observations \\
- Banks with missing data & 800 & 10400 \\
Total banks retained & $(260)$ & 3380 \\
\hline Panel B: Sample distribution by region & 540 & 7020 \\
\hline Region & Observations & $\%$ \\
\hline Africa & 663 & 9.41 \\
Asia & 897 & 12.79 \\
America & 1404 & $20 \%$ \\
Europe & 3042 & 43.35 \\
Middle east & 1014 & 14.45 \\
Total & 7020 & 100 \\
\hline Notes: Panel A describes the sample selection; Panel B provides the distributional properties of the full \\
\multicolumn{2}{c}{ sample by region. Observations are the total of bank-years observations by region. }
\end{tabular}

\subsection{Variables measurement}

Our methodological approach consists in measuring the study variables, prior to presenting the research hypotheses' testing model.

\section{Dependent Variable: Bank Risk-Taking}

The aim of this study lies in exploring in what ways the different CEO associated characteristics prove to affect the bank risk-taking decisions, which entails implementing appropriate risk defining and measuring methods. For this purpose, three different risk measures are going to be applied as dependent variables in the regression analysis of this study. They are extensively used in the banking literature, and consist in the insolvency risk (ZSCORE), credit risk (NPL), as well as equity return volatility (SDVOL). In a first stage, we undertake to use the Z-score (Laeven and Levine, 2009; Skala and Weill, 2018; Ahmed et al., 2019; Zhou et al., 2019), measured as the sum of return on average asset (ROA) and equity to total assets ratio or capital asset ratio (CAR) divided by the ROA standard deviation over the sample period. Actually, the ZSCORE value is inversely related to the probability of bank insolvency, therefore, the higher the Z-score is, the greater the stability will be. Hence, a higher Z-score would indicate that the bank is less risky, therefore, more solvent. The Z-score is computed as follows:

$$
Z_{i t}=\frac{R O A_{i t}+C A R_{i t}}{\sigma R O A_{i t}}
$$


Respectively, for bank i in year t, ROAit denotes the bank's return on assets (ROA), CARit designates the bank's ratio of equity to assets, and $\sigma$ ROAit refers to the standard deviation corresponding to the assets' return rate, computed over the entire sample period.

In a second stage, the bank balance sheet metrics, such as the ratio capitalization or nonperforming loans (NPL), are used to estimate the bankruptcy likelihood, as initiated by Bennett and Unal (2010). In terms of credit risk, the higher the ratio attained is, the riskier the bank would turn out to be. In addition, the NPLs ratio represents an exposure to bank credit risk (Kabir et al., 2015), defined as the ratio of non-performing loans to total loans at the end of the fiscal year. This ratio serves to provide information concerning the quality of a bank's loan portfolio. It offers details about the bank's loan portfolio quality. Following a number of previously conducted research works (Becker and Stromberg, 2012; Elyasiani and Zhang, 2015; Cain and McKeon, 2016), the third and last risk-taking related measure turns out to be the monthly stock returns' standard deviation, annualized over a calendar year. The stock return volatility helps capture a bank's overall riskiness, and may be applied to reflect market perceptions of the risks inherent in the bank's business strategies, management, assets, liabilities, and off-balance sheet positions. These returns can be determined through application of the return simple formulation, such as:

$$
R_{t}=\frac{\left(P_{t}-P_{t-1}\right)}{P_{t-1}}
$$

where:

$R t=$ Return at time $\mathrm{t}$;

$P t=$ Stock price at time $\mathrm{t}$;

$P t-1=$ Stock price at time $\mathrm{t}-1$.

Descriptions of the risk-taking states and the related measuring variables are depicted on Table no. 2, below. The most well-known methodology, widely applied in this respect, also implemented in our study context, is the PCA (Principal Component Analysis). It is actually applicable after checking the correlation matrix determinant, the Kaiser-Meyer-Olkin (KMO) index, and the Bartlett test. It is a multivariate numerical tool that enables to transform the set of uncorrelated variables, also dubbed components of the correlated variables' set. The linear combination of these components involves original variables. The fundamental logic behind applying the PCA lies in helping to reduce the data set sizes and transform the mutually dependent coordinate(s) into significant and independent risk-taking coordinates.

Table no. 2, below, illustrates the variables (\%) contribution in terms of factors. Accordingly, the first two statements' factor loadings (0.6982 and 0.6942), respectively elucidate the significant importance of the Z-score and NPL. In effect, the Kaiser-Meyer Olkin measure, used to verify the analysis relevant sampling adequacy, has been $\mathrm{KMO}=0.702$, which is well above the acceptable limit of 0.6 (Kaiser, 1974). Similarly, the Bartlett's test has also been highly significant ( $\mathrm{p}<.001)$. As to the principal component analysis, it proved to reveal the presence of a component whose Eigen value exceeds 1, enabling to explain 34.6 per cent of variance. 
Table no. 2 - Results of Principal Component Analysis

\begin{tabular}{|c|c|c|c|}
\hline \multicolumn{4}{|c|}{ Panel A: Eigenvalues of the components } \\
\hline Components & Eigen values & Proportion & Cumulative \\
\hline Z_score & 1.0381 & 0.3460 & 0.3460 \\
\hline NPL & 0.9973 & 0.3324 & 0.6785 \\
\hline SDVOL & 0.9646 & 0.3215 & 1.0000 \\
\hline \multicolumn{4}{|c|}{ Panel B : KMO index and Bartlett's Test } \\
\hline Kaiser-Meyer-Olkin & 0.7019 & & \\
\hline Bartlett's Test & 4318.923 & & \\
\hline Df & 401 & & \\
\hline Sig & 0.000 & & \\
\hline \multicolumn{4}{|c|}{ Panel C: correlation matrix } \\
\hline & oading & unique vari & \\
\hline Z-score & 0.6982 & \multicolumn{2}{|c|}{0.5125} \\
\hline NPL & 0.6942 & \multicolumn{2}{|r|}{0.5180} \\
\hline SDVOL & 09314 & \multicolumn{2}{|r|}{0.9314} \\
\hline
\end{tabular}

\section{Independent variables}

It is necessary to identify the independent variables fit for implementation in the model, so that the complete/full model useful for application in the analysis could be effectively determined. The independent variables involve the numerical measurements of the CEOs' measurable features included in the sample, and will be used to assess whether these features are relevant to the above cited risk measures.

CEO dominance: Initially, we tend to consider the CEO's dominance as an independent variable. The natural logarithm of the CEO's total annual remuneration to the Bank's total assets stands as the principal proxy for CEO dominance, and is described as:

$$
\text { dom }=\log \left(\frac{\text { CEOremuneration }}{\text { Totalassets }}\right)
$$

where: CEO remuneration $=$ Basic salary + Director fees + Performance bonuses + Allowances \& Non-cash benefits.

Total assets $=$ measure of bank size .

CEO Overconfidence: We evaluate Bank level overconfidence of the CEO to be coded 1 if the total of the five below cited dummy variables is discovered to be equal to or greater than 3 , and 0 otherwise. These variables are:

- Net Acquisition $=$ a dummy variable equal to 1 if the net cash flow statement acquisitions appear to lie in the top quartile of bank $\mathrm{i}$ in year $\mathrm{t}$, and 0 otherwise.

- Debt-to - equity ratio = a dummy variable equal to 1 , where the debt-to-equities ratio proves to be sited in the highest quartile in year $\mathrm{t}$ for bank $\mathrm{i}$, and 0 otherwise. It is measured as the long-term debt plus short-term debt to total market value (=the market value of equity + the book values of long-term debt + preferred stock). 
- $\quad$ Risky Debt $=$ a dummy variable that is equal to 1 if the convertible or preferred stock proves to exceed zero, and 0.

- $\quad$ Dividend Yield = a dummy variable equal to 1 if the dividend yield is zero, and 0 otherwise.

- $\quad$ Excess Investment $(\mathrm{OVC})=$ a dummy variable equal to 1 when excess investment is in the bank's top for the year $t$, and 0 otherwise. It is measured as a residual variable from the regression in sales growth.

In this context, the CEOs' current investment decisions are used as a measure of their respective overconfidence level. The over-confidence investment proxy is the amount of excessive asset investment due to the residual of a regression of total assets growth on sales growth run by industry year. It is described as:

$$
\text { Invest }_{i t}=\beta_{0}+\frac{\text { Assetsgrowth }_{i t}}{\text { Salesgrowth }_{i t}}+\varepsilon_{i t}
$$

The investment model's error concept should reflect the investments related inefficiency, either through overinvestment or through underinvestment. If the residual of the excess investment regression is greater than zero, and otherwise 0 , we set OVC to be equal to 1 .

CEO dominance * CEO duality: it is a third-moderator variable that affects the intensity of interaction between an independent variable and a dependent one (Fritz and Arthur, 2017). In a relationship where $S$ stands as the variable predictor (first variable) and $T$ as a resultant variable (second variable), $Q$ should represent the moderator variable (third variable) affecting the $\mathrm{S}$ and $\mathrm{T}$ binding relationships (Kim et al., 2001). Hence, CEO duality would serve as the moderator variable between CEO dominance and bank risk-taking in the present analysis context. Thus, the moderator variable has been incorporated to help assess the intensity or weakness of such a relationship (Ahmed et al., 2019).

\section{Control variables}

As the main purpose of the present research work consists in checking the CEO's conduct effect on bank risk-taking policy, it is necessary to introduce a number of control variables likely to influence such a relationship. For this reason, the following control variables have been selected for our study case, namely, bank size, bank age, GDP real growth and inflation rate. The control variables' measures, along with the other variables related ones are summed up on Table no. 3, below.

Table no. 3 - Definition of variables

\begin{tabular}{llll}
\hline Variables & Codename & \multicolumn{1}{c}{ Definitions } & \multicolumn{1}{c}{ Sources } \\
\hline $\begin{array}{l}\text { Dependent variable } \\
\text { insolvency risk }\end{array}$ & Z-score & $\begin{array}{c}\text { the natural logarithm of } \\
Z_{i t}=\frac{R O A_{i t}+C A R_{i t}}{\sigma R O A_{i t}}\end{array}$ & $\begin{array}{l}\text { Thomson Reuter } \\
\text { (DataStream) }\end{array}$ \\
Credit risk & NPL & $\begin{array}{l}\text { Ratio of non-performing } \\
\text { loans over total loans }\end{array}$ & $\begin{array}{l}\text { Thomson Reuter } \\
\text { (DataStream) }\end{array}$
\end{tabular}




\begin{tabular}{|c|c|c|c|c|}
\hline Variables & Codename & Definitions & \multicolumn{2}{|l|}{ Sources } \\
\hline $\begin{array}{l}\text { volatility of stock } \\
\text { returns }\end{array}$ & SDVL & $\begin{array}{l}\text { Standard deviation of annual } \\
\text { stock returns }\end{array}$ & \multicolumn{2}{|l|}{$\begin{array}{l}\text { Thomson Reuter } \\
\text { (DataStream) }\end{array}$} \\
\hline \multicolumn{5}{|l|}{ Independent variable } \\
\hline CEO dominance & CEO_DOM & $\begin{array}{l}\text { Log (CEO remuneration/total } \\
\text { assets) }\end{array}$ & Annual report & \\
\hline CEO overconfidence & CEO_OVER & $\begin{array}{l}\text { Dummy variable which takes } \\
\text { the value of } 1 \text { if the residual } \\
\text { from the excess investment } \\
\text { regression is greater than zero } \\
\text { and } 0 \text { otherwise. }\end{array}$ & Annual report & \\
\hline CEO duality & CEO_DUAL & $\begin{array}{l}\text { Dummy variable which equals } 1 \\
\text { when the CEO is also the } \\
\text { chairman of the board and } 0 \\
\text { otherwise. }\end{array}$ & Annual reports & \\
\hline \multicolumn{5}{|l|}{ Control variables } \\
\hline Bank size & SIZE & Log (Total of total assets) & $\begin{array}{l}\text { Thomson } \\
\text { (Datastream) }\end{array}$ & Reuters \\
\hline Bank age & AGE & $\begin{array}{l}\text { Number of years since a bank is } \\
\text { established. }\end{array}$ & $\begin{array}{l}\text { Thomson } \\
\text { (Datastream) }\end{array}$ & Reuters \\
\hline GDP real growth & GDPG & $\begin{array}{l}\text { Annual Gross domestic product } \\
\text { growth rate }\end{array}$ & $\begin{array}{l}\text { World Deve } \\
\text { Indicators (WI }\end{array}$ & $\begin{array}{l}\text { elopment } \\
\text { DI) }\end{array}$ \\
\hline Inflation rate & INF & $\begin{array}{l}\text { Annual percent change of } \\
\text { average consumer price index. }\end{array}$ & $\begin{array}{l}\text { World Deve } \\
\text { Indicators (WI }\end{array}$ & $\begin{array}{l}\text { elopment } \\
\text { DI) }\end{array}$ \\
\hline
\end{tabular}

Notes: This table reports the definitions of the variables used in the study.

\subsection{Research model}

With regard to our special context, we consider opting for the following multiple regression for the purpose of empirically testing the major posited assumptions, advancing that bank risk-taking strategies change with changing CEO behavior. The regression to apply is:

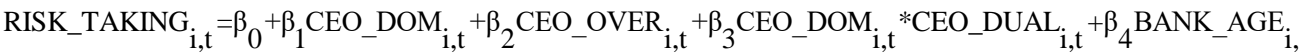

$$
\begin{aligned}
& +\beta_{5} \text { BANK_SIZE }_{\mathrm{i}, \mathrm{t}}+\beta_{6} \mathrm{GDP}_{-} \mathrm{G}_{\mathrm{i}, \mathrm{t}}+\beta_{7} \mathrm{INF}_{\mathrm{i}, \mathrm{t}}+\sum_{i=8}^{20} \beta_{i} \text { year }_{i, t}+\sum_{j=21}^{54} \beta_{j} \text { country }{ }_{j, t}+\varepsilon_{\mathrm{i}, \mathrm{t}}
\end{aligned}
$$

The entirety of implemented variables is already defined on Table no. 3. Year and Country stand respectively for the concerned year and country, while $\varepsilon$ denotes the error term and the indices: $i$ and $t$ respectively signify the concerned banks and the year.

\section{RESULTS AND DISCUSSION}

\subsection{Summary statistics}

Table no. 4, below, provides the CEO behavior, bank risk-taking, and control variables associated statistics. Accordingly, based on Panel A, which depicts the dependent variables relating descriptive statistics, the average proportion of factor turns out to be $2.56_{0.9}^{-1}$, while the standard deviation is of the rate of 1.315. As regards the risk-taking extent, it proves to 
range from a minimum of -1.848 to a maximum of 29.283. The high risk-taking rates and their wide ranges imply well the persistence of a substantial variation in bank risk levels. According to Panel B, which reports the continuous variables relating descriptive statistics, the average CEO dominance (CEO_DOM) is of the rate of -2.327 , suggesting that CEO dominance is relatively low across the banking firms' sample.

The CEO proves to occupy simultaneously the post of Chairman of the board (CEO_DUAL) with respect to almost $41 \%$ of the sample banks, while the average proportion of CEO overconfidence is 0.316 . Hence, CEO overconfidence turns out to play a noticeable role in the banking sector related risk-taking scope. As highlighted through Table no. 3, the variable 'size' appears to range from 10.731 to 27.976, reflecting a large dispersed distribution. Overall, one could well deduce that the sample proves to consist of relatively large banks.

Similarly, Table no. 4 suggests that the banks' average age is 68.73761 years. It is also worth noting a high deviation proves to persist between the minimum 10 and the maximum 197, registering a standard deviation rate of 41.412. Similarly, the same table depicts an average GDP growth rate of 3.486, recording a standard deviation of 4.389. In fact, the GDP increase is discovered to range between a minimum of -9.132 , and a maximum of 26.17 . The mean inflation rate (INF) relevant to the sample countries is around 3.163.

Table no. 4 - Descriptive statistics of the sample

\begin{tabular}{|c|c|c|c|c|c|}
\hline Variable & Obs. & Mean & SD & Min & Max \\
\hline \multicolumn{6}{|c|}{ Panel A : The dependent variables: risk-taking } \\
\hline Risk_Taking & 7020 & 6.296 & 1 & -1.848 & 29.283 \\
\hline \multicolumn{6}{|c|}{ Panel B : The continuous variables } \\
\hline CEO_DOM & 7020 & -2.327 & 1.196 & -5.929 & -.075 \\
\hline CEO OVER & 7020 & 0.316 & 0.171 & 0 & 0.8 \\
\hline SIZE & 7020 & 18.547 & 3.085 & 10.731 & 27.976 \\
\hline AGE & 7020 & 68.738 & 41.412 & 10 & 197 \\
\hline GDPG & 7020 & 3.486 & 4.389 & -9.132 & 26.170 \\
\hline INF & 7020 & 3.163 & 3.726 & -4.863 & 29.507 \\
\hline \multicolumn{6}{|c|}{ Panel C: The dichotomous independent variables } \\
\hline & & Modality & & $\%$ & \\
\hline \multirow[t]{2}{*}{ CEO_DUAL } & & 0 & & 59 & \\
\hline & & 1 & & 41 & \\
\hline
\end{tabular}

Note: Variables definitions are provided in Table no. 3.

\subsection{Correlation analysis}

Table no. 5, below, illustrates the Pearson associations perceived among the regression variables. The entirety of correlations is discovered to be lower than 0.3 in absolute value, thereby, the variables turn out to capture unique aspects of bank risk-taking. CEO_DOM is positively associated with each of the model applied underlying variables. While CEO overconfidence proves to be negatively associated with GDP growth and inflation, it turns out to be positively associated with the other variables. Besides, a positive association has also been recorded between the variable (CEO_DOM*CEO_DUAL) and other independent variables. Consequently, one can well note the absence of any multicollinearity problems within the analysis. To check the existence of any multicollinearity problem, we consider 
computing the variance inflation factor VIF. Actually, the values reached appear to range between 1.068 and 1.376, i.e., they are sited below the critical value 5 (Groebner et al., 2008). Therefore, no multicollinearity problem seems to be generated by the independent variables correlations.

Table no. 5 - Pearson correlation matrix and Variance inflation factor

\begin{tabular}{lccccccc}
\hline \multicolumn{1}{c}{ Variables } & $(\mathbf{1})$ & $\mathbf{( 2 )}$ & $\mathbf{( 3 )}$ & $\mathbf{( 4 )}$ & $\mathbf{( 5 )}$ & $\mathbf{( 6 )}$ & $\mathbf{( 7 )}$ \\
\hline (1) CEO_DOM & 1.000 & & & & & & \\
(2) CEO-OVER & $0.053^{*}$ & 1.000 & & & & & \\
& $(0.011)$ & & & & & & \\
(3) CEO_DOM* & $0.050^{*}$ & 0.023 & 1.000 & & & & \\
CEO_DUAL & $(0.015)$ & $(0.260)$ & & & & & \\
(4) SIZE & $0.298^{*}$ & $0.116^{*}$ & $0.099^{*}$ & 1.000 & & & \\
& $(0.000)$ & $(0.000)$ & $(0.000)$ & & & & \\
(5) AGE & $0.082^{*}$ & $0.213^{*}$ & $-0.066^{*}$ & $0.289^{*}$ & 1.000 & & \\
& $(0.000)$ & $(0.000)$ & $(0.001)$ & $(0.000)$ & & & \\
(6) GDPG & $0.044^{*}$ & $-0.108^{*}$ & 0.024 & $-0.154^{*}$ & $-0.135^{*}$ & 1.000 & \\
& $(0.034)$ & $(0.000)$ & $(0.247)$ & $(0.000)$ & $(0.000)$ & & \\
(7) INF & 0.014 & $-0.115^{*}$ & 0.021 & $-0.063^{*}$ & $-0.138^{*}$ & $0.290^{*}$ & 1.000 \\
& $(0.294)$ & $(0.000)$ & $(0.320)$ & $(0.002)$ & $(0.000)$ & $(0.000)$ & \\
\hline VIF & 1.228 & 1.109 & 1.068 & 1.376 & 1.28 & 1.191 & 1.22 \\
\hline
\end{tabular}

Notes: Variables definitions are provided in Table no. 4. $*, * *, * * *$ Indicates significance at the $10 \%, 5 \%$, and $1 \%$ levels, respectively.

\subsection{Multivariate analyses}

The results, figuring on Table no. 6, reveal the panel data results relevant to the CEO characteristics' impact on bank risk-taking concerning the entirety of the study sample considered banks. The $\mathrm{p}$-value of F-statistics is discovered to be significant $(\mathrm{F}=9.42 ; \mathrm{p}=$ 0.000 ) at the $1 \%$ level, testifying well the model fitness. Additionally, the adjusted R2 provides that a proportion of 68 per cent of the variations reported by the explanatory variables turn out to affect the dependent variable noticeably. To sum it up, the model turns out to be globally significant and explanatory. In this respect, special tests have been administered to select the most appropriately fit among the panel-data model estimating methods. Actually, the Wald test demonstrated a rather noticeable advantage of the fixed effect model ( $\mathrm{p}$-value $<0.05$ ) over the pooled model. In turn, the Hausman test also indicated that the fixed effect model proved to match even better than the random one ( $p$-value<0.05). The heteroscedasticity test (the Wald's panel data model heteroscedasticity test) proved to reject the model's homoscedasticity hypothesis at the level of 1 percent. Accordingly, the model can be reckoned and considered to stand as a regression with fixed effects.

It is worth noting, at this level, that the study empirical findings appear to highlight well the significant relationship binding CEO dominance and risk-taking. The Model achieved results, figuring on Table no. 5, prove to reveal well that the CEO dominance associated coefficient is positive $(0.0425)$ and significant at the $5 \%$ threshold $(\mathrm{p}=0.034)$, denoting well that a higher CEO dominance helps induce managers to undertake high-risk projects. Indeed, a negative association proves to persist between CEO dominance and risk taking. Hence, the first hypothesis advanced turns out to be accepted. In effect, the risk decisions promoting level 
has its primary explanation in the CEO's emotional biases, such as over-dominant character. Such a finding proves to corroborate well that achieved by Bebchuk et al. (2011), suggesting that the extent of the agency dispute appears to get rather intensified in presence of a strong CEO dominance. This is consistent with previous findings of Cerasi et al. (2020) which indicate that greater compensation is highly advantageous in mitigating risk in the banking sector. These results proof that CEO dominance tends to increase agency costs and has an impact risk-taking. In addition, a CEO may participate in further extending or aggravating bank risk, for instance, by getting involved in skeptical diversification decisions, in a bid to strengthen the chance of achieving greater profit increases. In fact, the CEOs associated dominance tends to provide and equip them with the means enabling them to pursue a risktaking penchant, while such acts have not been ahead subject to board evaluation or vigilance. These results indicate well that banks tend to engage in a wider range of risk-taking practices across diversified risk taking strategies, once the CEO turns out to be remarkably dominant. When it comes to risk-taking, institutional investors are usually aligned, and dominant CEOs may influence board decisions to enforce risky policies.

As regards the second hypothesis (H2), the coefficient for overconfidence proves to be negative (-0.4249) and statistically significant $(\mathrm{p}=0.001)$ at the $1 \%$ level, highlighting well that the hypothesis postulate is actually confirmed. Such a finding appears to conform with a number of already published studies, mainly those conducted by Malmendier and Tate (2015) and Kamiya et al. (2019) who showed that Overconfident CEOs that managed banks take less risks. On the basis of the agency theory, the manager overconfidence influences strategic decisions. In effect, a highly overconfident CEO could well contribute in incurring a possible expected reduction in loan portfolio efficiency, unlike the other less confident executives. Overconfident CEOs tend to believe that they enjoy superior decision-making capabilities and are more competent than their peers. It is actually the predominance of such cognitive biases that entices CEOs to emphasize their judgments in matters of decision-making and take a highly nuanced stance to transactions. Hence, too great an overconfidence may provide explanation as to why managers dare to risk significant wealth losses and keep exposing their banks to noticeable risktaking ventures. Thus, the bank directors' excessive-confidence tendency appears to affect not only their decision-making influence, but also the level of their risk-taking potential. Indeed, CEO overconfidence helps in greatly alienating or distorting the banks' investment decisions, for on adopting a rather aggressive approach, over-confident bank CEOs often tend to pursue rather lenient lending policies to borrowers. On the other hand, it has also been discovered that the overconfident CEOs associated risky ventures do not seem to compensate stakeholders, whose funds usually achieve the same return rates and are liable to encounter greater underfunding problems, as compared to those funds run by cautious CEOs. Thus, one may conclude by saying that overconfident bank CEOs would take exposures or ventures they reckon and perceive to be the most highly profitable for shareholders.

Concerning the third hypothesis relating empirical findings, the reached results proved to reveal the persistence of a negative $(-0.0076)$ and significant interaction effect on the relationship $(\mathrm{p}=0.036)$ at $5 \%$ level. Hence, $\mathrm{H} 3$ proves to be effectively supported. This finding appears to highlight that the positive link between CEO dominance and the bank risk-taking strategy turns out to weaken or be rather attenuated with CEO duality. Such a finding proves to be in line with the agency theory postulate that power concentration in the hands of dual CEOs, and the resultant weak board, contribute to a lower risk-taking tendency within the bank. Still, the bank CEO's dominance would improve overall levels of agreeableness within 
the institution. Similarly, CEO duality may also represent a natural corollary that paves the way for a dominant CEO. Naturally, the extremely dominant CEOs are likely to display excessive appetite for authority, so they would constantly attempt to influence and persuade the board to be simultaneously elected as chairmen. Generally, CEO duality has a significantly negative effect, by jeopardizing and weakening the positive relationship binding CEO dominance and risk-taking strategy. This finding is actually consistent with Duru et al. (2016) reached results relating to the value of CG practices, supporting the idea that banks with effective CG structures are more likely to construct rather reliable investment trust, thereby, endure and incur lower risk levels.

Our achieved statistical results tend to highlight that the four control variables advanced appear to have a noticeable impact on risk-taking. In this context, the control variable 'bank size' proves to stand as an important determinant of bank risk-taking. Indeed, the relevant coefficient appears to be negative $(-0.078)$ and statistically significant $(\mathrm{t}=-4.71$, and $\mathrm{p}=$ 0.000 ) at the $1 \%$ level. This finding indicates well that smaller banks usually tend to have lower risk rates relevant to larger banks. Such results tend to support the argument 'too big to fail', according to which, small banks are more likely to take greater risk levels. It is also possible for bigger banks to have effective risk management functions. This supports the argument that the large banks tend to manage their losses rather efficiently, since they exhibit greater opportunities to pursue a broader spectrum of credit, investment and other activities. Bank Age is discovered to exert a significantly negative influence $(\beta=-0.0054, p=0.000)$ on risk-taking at the $1 \%$ level. This result demonstrates well that this variable proves to display a noticeable impact on the model's explanatory power. Such a finding proves to be in line with those published by Shahbaz Sheikh (2019) and Haque and Ntim (2018). In addition, the Old aged banks are discovered to be rather cautious towards risk-taking than younger aged ones, mainly because they are less likely to face competition. Older banks are usually more likely to resist the temptation of a dangerous transition.

Regarding the macroeconomic factor, the GDP growth coefficient proves to be negative ($0.3916)$ and statistically significant $(\mathrm{p}=0.035)$, denoting that a rise in economic growth would have a negative impact on bank risk-taking. Similarly, a higher GDP level would help decrease risk at the bank level and enhance the risk-taking behavior. This finding corroborates the result attained by Altunbas et al. (2020), indicating that increased GDP helps increase bank lending, lower standards and increase risk-taking activity. It also highlights that economic growth gives impetus to the borrowers' willingness to repay their loans, thus, minimizing the banks' insolvency risks and the amount of bad loans incurred. Indeed, banks sited in countries with high economic growth tend to have smaller portions of bad loans and to be less volatile.

The inflation related coefficients are discovered to be positive and statistically significant $(\beta=0.241$ and $p=0.003)$ at $1 \%$ level of risk-taking. The inflation rate plays an uncertain role in assessing the amount of risk incurred by banks. Inflation variability leads lenders to measure the value of loan collateral and the borrowers' loan-repayment capacities. Consequently, a stable and constant inflation rate would help decrease debt real value, thereby, reducing the amounts of banks' incurred risks. Excessive inflation, however, may well deplete the borrowers' real income and sharpen bank risk, particularly when income does not prove to increase proportionately with inflation. 
Table no. 6 - Results of multivariate analysis Models

\begin{tabular}{lll}
\hline Variables & Coefficient & T-statistic \\
\hline CEO_DOM & $0.043^{* *}$ & 2.12 \\
CEO_OVER & $-0.425^{* * *}$ & -3.26 \\
CEO_DOM*CEO_DUAL & $-0.008^{* *}$ & -2.22 \\
SIZE & $-0.078^{* * *}$ & -4.71 \\
AGE & $-0.005^{* * *}$ & -3.84 \\
GDPG & $-0.392^{* * *}$ & -2.85 \\
INF & $0.241^{* * *}$ & 2.79 \\
Constant & $1.293 * * *$ & 3.43 \\
Year fixed effects & YES & \\
Country fixed effects & YES & \\
$\mathrm{R}^{2}$ & 0.68 & \\
F & 9.42 & \\
p-value & 0.000 & \\
Wald-test & $\chi 2(\mathrm{k})=92.80(0.000)$ \\
Hausman's test & $\chi 2(\mathrm{k})=8.441(0.000)$ \\
\hline \multicolumn{2}{c}{ Notes: Variables definitions are provided in Table no. 4.} \\
$*, * *, * * *$ Indicates significance at the $10 \%, 5 \%$, and $1 \%$ levels, respectively.
\end{tabular}

\section{ROBUSTNESS TEST}

To assess the robustness of our attained findings, we consider splitting the analysis and extending it even further to attain rather reliable results. Therefore, for an effective improvement of the present conducted study, we recommend to elaborate on a regional analysis of classifications. To this end, we first consider to split the banks' full sample into sub-samples reflecting the different regions. Second, we undertake to run the relevant regression to check whether the results reached would appear to differ from the already attained regression results, as figuring on Table 18, with respect to each sub-sample. Accordingly, we suggest running separate regressions relevant to the banks pertaining to such regions as "America", "Europe", "Asia", "and the "Middle East" and "Africa".

In conformity with the first set hypothesis, $\mathrm{H} 1$, the CEO dominance coefficient estimate is discovered to be optimistic and significantly important, at the level of 1 percent, with respect to the regions of America, Europe, the Middle East and Africa. Furthermore, the CEO dominance related coefficient proves to be positive and significantly important, at the 5 percent threshold, concerning the European region. The findings also indicate that CEO overconfidence turns out to have a significantly negative effect with respect to the American area, but a significantly negative effect regarding the other regions. Indeed, the relationship term between CEO supremacy and CEO duality proves to bear a positive and important coefficient as regards the region of America, yet, a negative effect on the other regions bearing a high coefficient. Besides, the regression tends to reveal that bank size appears to be statistically unimportant in regard to the Asian area, suggesting that bank size proves to have no direct impact on risk-taking. As regards the other regions, bank size has been discovered to be strongly and negatively correlated with risk-taking. In addition, the findings also suggest that bank age turns out to be positively and statistically important for the regions of America, Europe, the Middle East and Africa, where bank age tends to increase riskiness for banks. On the other hand, it has been discovered that risk-taking does not seem to affect the Asian banks' 
age. It is also worth noting that GDP growth appears to help decrease the level of risk-taking in the American region with respect to macroeconomic control variables.

Nevertheless, GDP growth appears to demonstrate a positive and statistically significant association with risk-taking regarding the Asian, the Middle Eastern and African regions based banks. However, no significant effect of GDP growth has been noticed with respect to the European region. As for the inflation rate, it proves to be highly statistically and significantly correlated with the developed regions (America and Europe). Noteworthy, however, is that, no major significant inflation effect on risk-taking has been observed with regard to the under-developed areas.

\section{CONCLUSION}

It is important to note that the CEOs' decision-making strategies prove to vary across banks, depending on their dominance degree within the organization. It also worth noting that, in some banks, it is the CEO who is entitled to make all relevant decisions, while in other banks, this role is jointly allotted to the CEO along with other executive teams. In this respect, several classic studies appear to emphasize the importance of managerial risk-taking enhancing mechanisms, for a rather effective alignment of the managers' interests with the shareholders' interests to take place. More recently conducted research, however, tends to emphasize the importance of the CEO conduct associated characteristics in investigating the risk-taking issue. With respect to our study context, however, a sample of 540 worldwidesited banks have been examined, over the period ranging between 2007 and 2019, to investigate in what ways CEO behavior appears to relate to bank risk-taking policy.

The achieved empirical findings prove to suggest that a positive and significant association turns out to persist between the bank's risk-taking strategy and CEO dominance. These results add to the debate concerning justified pay combinations for corporate executives, and appear to display significant outcomes as to the design of compensation packages through accounting for the executives' distinctive characteristics. This result is consistent with those of Victoravich et al. (2011), Altunbas et al. (2020). These authors show considering that CEO dominance is an important factor of bank risk-taking. In effect, CEO dominance proves to stand as a critical factor and an important dimension lying behind the high-level risk-taking venture. On the one hand, a remarkably dominant CEO is more liable to encounter high-risk levels. On the other hand, CEO overconfidence might well bring about significantly negative effects on banking risk-taking strategy. This finding is consistent with previous research by Black and Gallemore (2013) and Ho et al. (2016), which found that overconfident CEOs overvalue their borrowers' prospects, put less emphasis on downside risk, and thus loosen lending standards. For while the highly overconfident CEOs tend to aspire investing in the least risky projects, CEOs with overconfidence attributes are more likely to pursue projects exhibiting very low risk levels. Finally, it has been discovered that CEO duality helps in weakening the positive relationship binding CEO dominance and risk-taking, while improving the risk decision reducing or attenuating process through implementation of effective corporate governance mechanisms.

In effect, the reached results appear to exhibit several implications. In a first place, they tend to confirm the view that an over-dominant bank CEO is likely to kindle the executives' risky behavior. As a matter of fact, the bank CEOs' remuneration package should be on par with market standards, while their multi-directional aims should vanish completely for them 
to focus exclusively on the rather valuable responsibilities and tasks. Moreover, should CEO over-confidence be negatively associated with inconvenient bank risk-taking policies, bank managers could likely well opt for low risk ventures and projects due to their non-diversifiable assets, including the human capital and relatively fixed bank pays. Instead, it seems rather necessary that the highly overconfident CEO should actually be invited to contribute in helping reduce the risk-taking practices within the banking sector. These contributions presume that the bank's risk is selected directly by the CEO. It is sufficient in this situation to ensure that the CEO's remuneration is set appropriately. Our findings show how important it is to consider the corporate governance of banks when evaluating the efficacy and limits of CEO remuneration. Hence, it is the role of the central government authorities to set the convenient criteria and adequate rules relevant to the CEO's selection process, which have to be rather realistic and more market focused. On the other hand, the paper provides new evidence that is particular to the banking industry.

Like any other study, the present work may well display some limitations, likely to pave the way for new research venues. Firstly, we do recognize that applying certain corporategovernance process proxies, i.e., CEO dominance, and bank risk taking, may not adequately help in capturing the specific mechanisms or results encountered by banks in the financial marketplace. Secondly, it seems imposed to incorporate a number of other effective variables displaying rather relevant effects on bank risk-taking issue, which have not been introduced in our model, mainly, CEO narcissism.

\section{References}

Aabo, T., Hvistendahl, N. T., and Kring, J., 2020. Corporate risk: CEO overconfidence and incentive compensation. Managerial Finance, 47(2), 244-265. http://dx.doi.org/10.1108/MF-05-2020-0278

Abatecola, G., and Cristofaro, M., 2018. Hambrick and Mason's "Upper Echelons Theory": Evolution and open avenues. Journal of Management History, 26(1), 116-136.

Abdul Hamid, B., Azmi, W., and Ali, M., 2020. Bank Risk and Financial Development: Evidence From Dual Banking Countries. Emerging Markets Finance \& Trade, 56(2), 286-304. http://dx.doi.org/10.1080/1540496X.2019.1669445

Adams, M., and Jiang, W., 2017. Do chief executives' traits affect the financial performance of risktrading firms? Evidence from the UK insurance industry. British Journal of Management, 28(3), 481-501. http://dx.doi.org/10.1111/1467-8551.12222

Ahmed, S., Sihvonen, J., and Vahamaa, S., 2019. CEO facial masculinity and bank risk-taking. $\begin{array}{llll}\text { Personality and Individual } & \text { Differences, }\end{array}$ http://dx.doi.org/10.1016/j.paid.2018.09.029

Altunbas, Y., Thornton, J., and Uymaz, Y., 2020. The effect of CEO power on bank risk: Do boards and institutional investors matter? Finance Research Letters, 33, 101202. http://dx.doi.org/10.1016/j.frl.2019.05.020

Anilov, A. E., and Ivashkovskaya, I. V., 2020. Do boards of directors affect CEO behavior? Evidence from payout decisions. The Journal of Management and Governance, 24(4), 989-1017. http://dx.doi.org/10.1007/s10997-019-09491-z

Azila-Gbettor, E. M., Honyenuga, B. Q., Berent-Braun, M. M., and Kil, A., 2018. Structural aspects of corporate governance and family firm performance: A systematic review. Journal of Family Business Management, 8(3), 306-330. http://dx.doi.org/10.1108/JFBM-12-2017-0045

Bandiera, O., Prat, A., Hansen, S., and Sadun, R., 2020. CEO behavior and firm performance. Journal of Political Economy, 128(4), 1325-1369. http://dx.doi.org/10.1086/705331 
Bauweraerts, J., and Colot, O., 2018. Exploring Top Management Team Composition in Private Family Firms. International Advances in Economic Research, 24(3), 283-284. http://dx.doi.org/10.1007/s11294-018-9697-5

Bebchuk, L. A., Cremers, K. M., and Peyer, U. C., 2011. The CEO pay slice. Journal of Financial Economics, 102(1), 199-221. http://dx.doi.org/10.1016/j.jfineco.2011.05.006

Becker, B., and Stromberg, P., 2012. Fiduciary duties and equity-debtholder conflicts. Review of Financial Studies, 25(6), 1931-1969. http://dx.doi.org/10.1093/rfs/hhs006

Behr, P., and Wang, W., 2020. The (un)intended effects of government bailouts: The impact of TARP on the interbank market and bank risk-taking. Journal of Banking \& Finance, 116, 105820. http://dx.doi.org/https://doi.org/10.1016/j.jbankfin.2020.105820

Beltratti, A., and Stulz, R. M., 2012. The credit crisis around the globe: Why did some banks perform better? Journal of Financial Economics, 105(1), 1-17. http://dx.doi.org/10.1016/j.jfineco.2011.12.005

Bennett, R. L., and Unal, H., 2010. The cost effectiveness of the private-sector resolution of failed bank assets. FDIC Center for Financial Research Working Paper, 2009-11.

Benzing, J., and Börner, C. J., 2015. The link between CEO incentive structures, managerial power, and firm risk in the financial services industry: A comprehensive analysis of US banking and insurance firms. Corporate Ownership \& Control, 371.

Black, D. E., and Gallemore, J., 2013. Bank executive overconfidence and delayed expected loss recognition. SSRN, 2144293.

Borio, C., and Zhu, H., 2012. Capital regulation, risk-taking and monetary policy: A missing link in the transmission mechanism? Journal of Financial Stability, 8(4), 236-251. http://dx.doi.org/10.1016/j.jfs.2011.12.003

Boungou, W., 2020. Negative interest rates policy and banks' risk-taking: Empirical evidence. Economics Letters, 186, 108760. http://dx.doi.org/10.1016/j.econlet.2019.108760

Brammertz, W., 2010. Risk and regulation. Journal of Financial Regulation and Compliance, 18(1), 4655. http://dx.doi.org/10.1108/13581981011019624

Broll, U., Welzel, P., and Wong, K. P., 2018. Ambiguity preferences, risk taking and the banking firm. Eurasian Economic Review, 8(3), 343-353. http://dx.doi.org/10.1007/s40822-018-0096-2

Cain, M. D., and McKeon, S. B., 2016. CEO personal risk-taking and corporate policies. Journal of $\begin{array}{llll}\text { Financial and } \quad \text { Quantitative } & \text { Analysis, }\end{array}$ http://dx.doi.org/10.1017/S0022109016000041

Caliskan, D., and Doukas, J. A., 2015. CEO risk preferences and dividend policy decisions. Journal of Corporate Finance, 35, 18-42. http://dx.doi.org/10.1016/j.jcorpfin.2015.08.007

Calomiris, C. W., and Ramirez, C. D., 2018. The Political Economy of Bank Entry Restrictions: A Theory of Unit Banking Public Choice Analyses of American Economic History (pp. 99-119): Springer. http://dx.doi.org/10.1007/978-3-319-95819-4_5

Cerasi, V., Deininger, S. M., Gambacorta, L., and Oliviero, T., 2020. How post-crisis regulation has affected bank CEO compensation. Journal of International Money and Finance, 104, 102153. http://dx.doi.org/10.1016/j.jimonfin.2020.102153

Chen, Z., and Ebrahim, A., 2018. Turnover threat and CEO risk-taking behavior in the banking industry. Journal of Banking \& Finance, 96, 87-105. http://dx.doi.org/10.1016/j.jbankfin.2018.08.007

Cheng, J. T., Tracy, J. L., Foulsham, T., Kingstone, A., and Henrich, J., 2013. Two ways to the top: Evidence that dominance and prestige are distinct yet viable avenues to social rank and influence. Journal of Personality and Social Psychology, 104(1), 103-125. http://dx.doi.org/10.1037/a0030398

De Haan, J., and Vlahu, R., 2016. Corporate governance of banks: A survey. Journal of Economic Surveys, 30(2), 228-277. http://dx.doi.org/10.1111/joes.12101

Desai, A., Kroll, M., and Wright, P., 2003. CEO duality, board monitoring, and acquisition performance: A test of competing theories. The Journal of Business Strategy, 20(2), 137. 
DeYoung, R., and Torna, G., 2013. Nontraditional banking activities and bank failures during the financial crisis. Journal of Financial Intermediation, 22(3), 397-421. http://dx.doi.org/10.1016/j.jfi.2013.01.001

Diallo, B., 2017. Corporate governance, bank concentration and economic growth. Emerging Markets Review, 32, 28-37. http://dx.doi.org/10.1016/j.ememar.2017.05.003

Doukas, J. A., and Petmezas, D., 2007. Acquisitions, overconfident managers and self-attribution bias. European Financial Management, 13(3), 531-577. http://dx.doi.org/10.1111/j.1468036X.2007.00371.x

Duru, A., Iyengar, R. J., and Zampelli, E. M., 2016. The dynamic relationship between CEO duality and firm performance: The moderating role of board independence. Journal of Business Research, 69(10), 4269-4277. http://dx.doi.org/10.1016/j.jbusres.2016.04.001

Elamer, A. A., AlHares, A., Ntim, C. G., and Benyazid, I., 2018. The corporate governance-risk-taking nexus: evidence from insurance companies. International Journal of Ethics and Systems, 34(4), 493-509. http://dx.doi.org/10.1108/IJOES-07-2018-0103

Elyasiani, E., and Zhang, L., 2015. Bank holding company performance, risk, and "busy" board of directors. Journal of Banking \& Finance, 60, 239-251. http://dx.doi.org/10.1016/j.jbankfin.2015.08.022

Fralich, R., and Fan, H., 2018. Legislative political connections and CEO compensation in China. Asian Business \& Management, 17(2), 112-139. http://dx.doi.org/10.1057/s41291-018-0034-x

Friedman Peahl, A., Heisler, M., Essenmacher, L. K., Dalton, V. K., Chopra, V., Admon, L. K., and Moniz, M. H., 2020. A comparison of international prenatal care guidelines for low-risk women to inform high-value care. American Journal of Obstetrics and Gynecology, 222(5), 505-507. http://dx.doi.org/10.1016/j.ajog.2020.01.021

Fritz, M. S., and Arthur, A. M., 2017. Moderator Variables: Oxford University Press.

Geiler, P., and Renneboog, L., 2016. Executive remuneration and the payout decision. Corporate Governance, 24(1), 42-63. http://dx.doi.org/10.1111/corg.12127

Gervais, S., Heaton, J. B., and Odean, T., 2011. Overconfidence, compensation contracts, and capital budgeting. The Journal of Finance, 66(5), 1735-1777. http://dx.doi.org/10.1111/j.15406261.2011.01686.x

Gomulya, D. M., Wong, E. M., and Ormiston, M., 2019. CEO Dominance and Newly Public Firms' Survival. Academy of Management 1. http://dx.doi.org/10.5465/AMBPP.2019.14413abstract

Graham, J. R., Harvey, C. R., and Puri, M., 2013. Managerial attitudes and corporate actions. Journal of Financial Economics, 109(1), 103-121. http://dx.doi.org/10.1016/j.jfineco.2013.01.010

Groebner, D. F., Shannon, P. W., Fry, P. C., and Smith, K. D., 2008. Business Statistics: A DecisionMaking Approach (7th ed.): Prentice-Hall.

Gyamerah, S., Amo, H. F., and Adomako, S., 2020. Corporate governance and the financial performance of commercial banks in Ghana. Journal of Research in Emerging Markets, 2(4), 33-47. http://dx.doi.org/10.30585/jrems.v2i4.541

Hambrick, D. C., and Crossland, C., 2018. A Strategy for Behavioral Strategy: Appraisal of Small, Midsize, and Large Tent Conceptions of This Embryonic Community Behavioral Strategy in Perspective (Vol. 39, pp. 23-39): Emerald Publishing Limited. http://dx.doi.org/10.1108/S0742332220180000039002

Hambrick, D. C., and Mason, P. A., 1984. Upper echelons: The organization as a reflection of its top $\begin{array}{llll}\text { managers. Academy of Management Review, 9(2), 193-206. } & \end{array}$ http://dx.doi.org/10.5465/amr.1984.4277628

Handriani, E., Ghozali, I., and Hersugodo, H., 2021. Corporate governance on financial distress: Evidence from Indonesia. Management Science Letters, 11(6), 1833-1844. http://dx.doi.org/10.5267/j.msl.2021.1.020 
Haque, F., and Ntim, C. G., 2018. Environmental policy, sustainable development, governance mechanisms and environmental performance. Business Strategy and the Environment, 27(3), 415435. http://dx.doi.org/10.1002/bse.2007

Ho, P. H., Huang, C. W., Lin, C. Y., and Yen, J. F., 2016. CEO overconfidence and financial crisis: Evidence from bank lending and leverage. Journal of Financial Economics, 120(1), 194-209. http://dx.doi.org/10.1016/j.jfineco.2015.04.007

Kabir, M. N., Worthington, A., and Gupta, R., 2015. Comparative credit risk in Islamic and conventional bank. Pacific-Basin Finance Journal, 34, 327-353. http://dx.doi.org/10.1016/j.pacfin.2015.06.001

Kaiser, H. F., 1974. An index of factorial simplicity. Psychometrika, 39(1), 31-36. http://dx.doi.org/10.1007/BF02291575

Kamiya, S., Kim, Y. H., and Park, S., 2019. The face of risk: CEO facial masculinity and firm risk. European Financial Management, 25(2), 239-270. http://dx.doi.org/10.1111/eufm.12175

Kim, J. S., Kaye, J., and Wright, L. K., 2001. Moderating and mediating effects in causal models. Issues in Mental Health Nursing, 22(1), 63-75. http://dx.doi.org/10.1080/016128401750158768

Kisfalvi, V., Sergi, V., and Langley, A., 2016. Managing and mobilizing microdynamics to achieve behavioral integration in top management teams. Long Range Planning, 49(4), 427-446. http://dx.doi.org/10.1016/j.lrp.2015.12.015

Kolm, J., Laux, C., and Loranth, G., 2017. Bank regulation, CEO compensation, and boards. Review of Finance, 21(5), 1901-1932.

Laeven, L., and Levine, R., 2009. Bank governance, regulation and risk taking. Journal of Financial Economics, 93(2), 259-275. http://dx.doi.org/10.1016/j.jfineco.2008.09.003

Malmendier, U., and Tate, G., 2015. Behavioral CEOs: The role of managerial overconfidence. The Journal of Economic Perspectives, 29(4), 37-60. http://dx.doi.org/10.1257/jep.29.4.37

Minnick, K., and Rosenthal, L., 2014. Stealth compensation: Do CEOs increase their pay by influencing dividend policy? Journal of Corporate Finance, 25, 435-454. http://dx.doi.org/10.1016/j.jcorpfin.2014.01.005

O'Reilly, C. A., and Hall, N., 2021. Grandiose narcissists and decision making: Impulsive, overconfident, and skeptical of experts-but seldom in doubt. Personality and Individual Differences, 168, 110280. http://dx.doi.org/10.1016/j.paid.2020.110280

Orens, R., and Reheul, A. M., 2013. Do CEO demographics explain cash holdings in SMEs? European Management Journal, 31(6), 549-563. http://dx.doi.org/10.1016/j.emj.2013.01.003

Rezaee, Z., Alipour, M., Faraji, O., Ghanbari, M., and Jamshidinavid, B., 2020. Environmental disclosure quality and risk: the moderating effect of corporate governance: Sustainability Accounting, Management and Policy Journal.

Roll, R., 1986. The hubris hypothesis of corporate takeovers. The Journal of Business, 59, 197-216. http://dx.doi.org/10.1086/296325

Shapira, Z., 1995. Risk taking: A managerial perspective: Russell Sage Foundation.

Sheikh, S., 2019. CEO power and corporate risk: The impact of market competition and corporate governance. Corporate Governance, 27(5), 358-377. http://dx.doi.org/10.1111/corg.12285

Shrader, R. C., Simon, M., and Stanton, S., 2020. Financial forecasting and risky decisions: An experimental study grounded in Prospect theory. The International Entrepreneurship and Management Journal, ooo, 1-15. http://dx.doi.org/10.1007/s11365-020-00697-4

Skala, D., and Weill, L., 2018. Does CEO gender matter for bank risk? Economic Systems, 42(1), 6474. http://dx.doi.org/10.1016/j.ecosys.2017.08.005

Srivastav, A., and Hagendorff, J., 2016. Corporate governance and bank risk-taking. Corporate Governance, 24(3), 334-345. http://dx.doi.org/10.1111/corg.12133

Tang, J., and Crossan, M., 2017. Are dominant CEOs the saviors of troubled firms? Long Range Planning, 50(6), 782-793. http://dx.doi.org/10.1016/j.lrp.2016.03.002

Ting, H. I., Chueh, H., and Chang, P. R., 2017. CEO power and its effect on performance and governance: Evidence from Chinese banks. Emerging Markets Review, 33, 42-61. http://dx.doi.org/10.1016/j.ememar.2017.09.005 
Vandekerkhof, P., Steijvers, T., Hendriks, W., and Voordeckers, W., 2019. The effect of nonfamily managers on decision-making quality in family firm TMTs: The role of intra-TMT power $\begin{array}{lllll}\text { asymmetries. Journal of Family Business Strategy, } 10(3), & 100272 .\end{array}$ http://dx.doi.org/10.1016/j.jfbs.2019.01.002

Victoravich, L., Buslepp, W. L., Xu, T., and Grove, H., 2011. CEO power, equity incentives, and bank risk taking. SSRN, 1909547, 1909547. http://dx.doi.org/10.2139/ssrn.1909547

Zhou, Y., Kara, A., and Molyneux, P., 2019. Chair-CEO generation gap and bank risk-taking. The British Accounting Review, 51(4), 352-372. http://dx.doi.org/10.1016/j.bar.2019.03.005

\section{Copyright}

c) (i) $(-)$ This article is an open access article distributed under the terms and conditions of the EY No No Creative Commons Attribution-NonCommercial-NoDerivatives 4.0 International License. 